\title{
Medical Augmented Reality and Virtual Reality
}

의료용 증강현실 및 가상현실

\begin{abstract}
Jaesung Hong, $\mathrm{PhD}^{*}$
Department of Robotics Engineering, Daegu Gyeongbuk Institute of Science \& Technology (DGIST), Daegu, Korea
\end{abstract}

Augmented reality (AR) or virtual reality is used in many fields, including medicine, education, manufacturing, and entertainment. With technical advances in optics, computer systems, and surgical instruments, AR applications to medicine are being vigorously researched. In particular, as surgeries using laparoscopy, endoscopy, or catheterized intervention have increased, AR plays an important role in many medical applications. AR is defined as a technique to combine the real world and virtual objects, which are digital content artificially generated by a computer. As another aspect of AR is the registration between the real world and virtual objects, it aims at an accurate estimation of the three-dimensional (3D) position and orientation of virtual objects related to the real world. Essentially, AR can allow users to see 3D virtual objects superimposed upon the real world. With the help of AR, a surgeon can view invisible organs during the surgery and improve the accuracy and safety of treatment procedures. After a brief description of the technical issues of medical AR, its applications will be introduced in this article.

Index terms Computer-Assisted Surgery; Image-Guided Surgery; Virtual Reality

\section{서론}

최근 각광을 받고 있는 증강현실 및 가상현실(virtual reality; 이하 VR) 기술은 의료 분야 에 효과적으로 적용될 수 있다. 특히 가상현실 분야는 스마트기기를 앞세운 최근의 카메라, 디스플레이, $\mathrm{CPU}$ 및 소프트웨어 기술의 발전에 힘입어 그 성능과 유용성이 높아지고 있다. 증강현실과 가상현실은 관련이 많은 기술이지만 현실과 어떻게 관계하느냐에 따라 구분할 수 있다. 먼저, 가상현실은 실체가 아닌 가상의 환경으로 실체처럼 보이고 느끼게 하는 기술 이라고 할 수 있다. 실물을 직접 이용하지 않기 때문에 훨씬 자유로운 환경과 조건에서 기술 을 활용할 수 있지만, 어디까지나 시뮬레이션의 세계이기에 실세계와의 차이가 존재할 수밖 에 없다. 그렇지만 위험성이나 비용 등의 이유로 실물을 직접 다루기 어려운 상황에서 많은 도움을 줄 수 있으며, 난이도가 있는 내시경 수술을 연습할 수 있는 의료용 시뮬레이터와 같 은 것이 대표적인 응용분야이다. 최근 삼성, 소니, 마이크로소프트나 구글과 같은 대기업들
Received January 25, 2019

Accepted March 22, 2019

${ }^{*}$ Corresponding author Jaesung Hong, PhD Department of Robotics Engineering, Daegu Gyeongbuk Institute of Science \& Technology (DGIST), 333 Techno jungangdaero, Hyeonpung-eup, Dalseong-gun, Daegu 42988, Korea.

Tel 82-53-785-6210

Fax 82-53-785-6209

E-mail jhong@dgist.ac.kr

This is an Open Access article distributed under the terms of the Creative Commons Attribution Non-Commercial License (https://creativecommons.org/ licenses/by-nc/4.0) which permits unrestricted non-commercial use, distribution, and reproduction in any medium, provided the original work is properly cited.

\section{ORCID iD}

Jaesung Hong (iD) https:// orcid.org/0000-0001-5429-8330 
이 헤드마운트디스플레이(head mounted display; 이하 HMD) 형식의 VR 시스템을 선보이고 있 다. 수십 년 이상의 역사를 지닌 기술이지만 최근에 다시 주목을 받고 있는데, 이를 의료에 적절히 사용하는 것은 긍정적인 방향으로 볼 수 있다. 다만 $\mathrm{HMD}$ 가 의료, 특히 수술실 환경에 적합한지에 대해서는 논란의 여지가 있다. 본 기고자를 포함해 전문가 중에는 수술 중 $\mathrm{HMD}$ 착용에 대해서 신 중한 의견을 표시하기도 한다.

한편, 증강현실은 현실과 좀 더 밀착한 기술로 볼 수 있다. 가상의 물체나 정보를 표시하지만 현 실을 떠나지 않고 현실 속에서, 현실의 물체들과 함께 표시된다. 현실과 가상이 공존하므로 몰입 감은 오히려 떨어질 수 있지만, 가상의 세계가 아니라 엄연히 실세계에서 일어나는 일을 경험한 다. 수년 전 크게 유행한 포켓몬고라는 게임이 대표적인 예이다. 가상의 캐릭터들이 실제 환경과 적절한 관계를 가지면서 등장한다. 사용자는 실제 도로를 걸으며 실제 건물과 자연 속에서 움직인 다. 따라서 증강현실은 가상현실을 포함하는 기술로도 생각할 수 있다. 실물과 가상을 적절히 함 께 다루어야 하기 때문에 구현하기에 더 복잡한 시스템이 되기도 한다. 하지만 현실과 현상에 충 실해야 하는 의료분야에서 증강현실은 가상현실이 제공할 수 없는 현실 정보를 제공할 수 있다. 본 기고에서는 증강현실에 중점을 두며, 특히 수술내비게이션 기술에 사용되는 증강현실에 대해 서 기술하고자 한다. 먼저 이론적인 부분을 소개하며, 기술적인 과제들과 몇몇 응용 예들에 대해 서술한다.

\section{수술과 의료영상}

과거 초음파, CT, MRI와 같은 의료영상들은 주로 진단을 위해 사용되었고, 수술 중 필요한 경우 다시 영상을 조회하는 정도로 활용되었다. 하지만 최근에는 영상유도수술 혹은 수술내비게이션으 로 일컫는 기술의 보급으로, 의료영상을 마치 여행 중에 지도를 보듯, 수술에 직접 활용하는 경우 가 많아졌다(Fig. 1). 자동차 내비게이션에서 지도가 기준이 되어 목적지와 현 위치를 표시하고 최 적의 경로를 계산하여 안내해 주는 것과 같이, 육안으로는 확인할 수 없는 병변의 위치를 의료영 상에서 확인하고 현재 수술부위를 또한 표시함으로써 목표하는 병변에 도달하기 위해 진행해야 할 방향이나 거리 등을 안내한다. 이와 같은 방식으로 수술내비게이션 기술은 목표하는 병변에 정 확히 도달할 수 있도록, 또한 그 과정에서 노출되는 혈관이나 신경을 보호하는 목적으로 사용된 다. 수술내비게이션은 점차 많은 수술에 보급되고 있으며, 특히 신경외과 영역, 이비인후과 영역 에서 많이 사용되어왔다. 지금까지 주로 경조직에 많이 사용되어 온 것은 연조직의 경우 수술 중 발생하는 조직의 변형이나 이동에 대응하기가 어렵기 때문이며, 이는 장차 극복되어야 할 기술적 인 과제로 남아 있다.

수술내비게이션을 실행하기 위해서는 의료영상과 환자의 좌표계를 맞추는 정합(registration) 과정을 수행해야 한다. 이를 위해서 보통 환자의 피부에 3개 이상의 마커를 부착한 채 의료영상을 획득한 후 영상에 보이는 마커와 환자에 부착한 마커의 대응관계를 이용하여 두 좌표 사이의 변환 행렬을 구한다. 이를 수행하면 의료영상에서 보이는 특정한 부위가 실제 환자 몸에서 어느 곳인지 알 수 있으며, 반대로 환자 몸에서 특정한 위치가 의료영상에서 어떤 곳에 해당하는지 알 수 있다. 


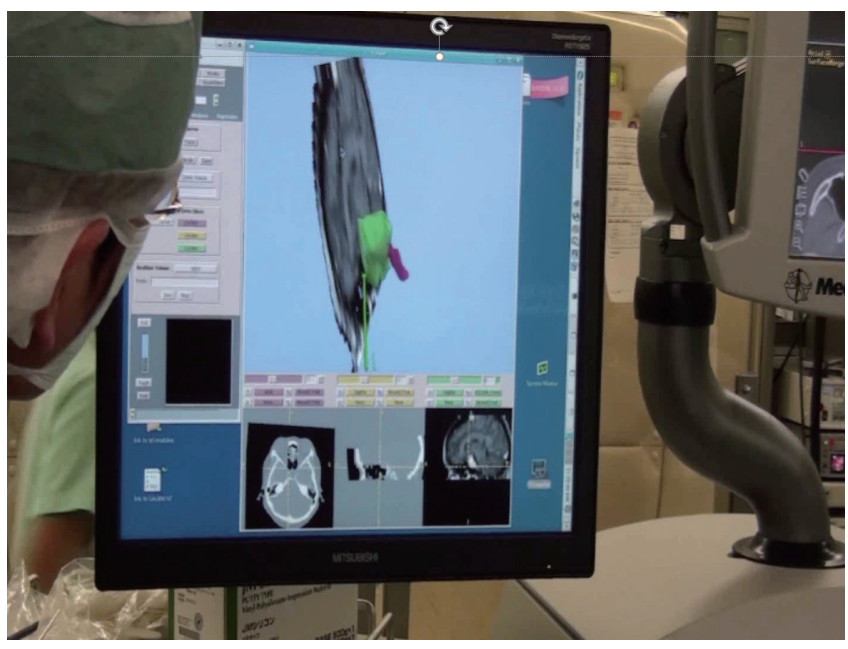

Fig. 1. Surgical navigation for pituitary tumor resection.

즉 의료영상에서만 보이는 특정 조직들을 환자 몸에서 찾을 수 있으며, 지금 수술도구로 치료하고 있는 조직이 CT나 MR 영상에서 어느 부위인지를 나타낼 수 있다. 이와 같은 수술내비게이션을 위해서 필요한 장비는 컴퓨터와 디스플레이 외에 위치추적센서가 있다. 위치추적센서의 역할은 우선 환자 좌표계를 정의하는 것이다. 영상 좌표계는 MRI나 CT 장비 자체의 좌표계도 있지만, 의 료영상을 표시하는 시각화 소프트웨어에서 잘 정의된다. 반면 환자 좌표계를 정의하기 위해서는 위치추적센서용의 마커를 환자의 몸에 부착하고 그 마커를 기준으로 정의하는 경우가 많다. 또한 대부분의 수술에서 환자나 수술대가 움직이기 때문에 위치추적센서는 움직이는 환자를 추적하기 위해 사용된다. 또한 많은 경우 수술도구의 위치를 의료영상 위에 표시하는 것이 필요하기 때문에 위치추적센서용 마커는 환자뿐 아니라 수술도구에도 부착되어 수술도구의 움직임을 실시간으로 추적, 표시한다. 수술내비게이션 화면의 구성은 전통적으로 axial, sagittal, coronal 세 단면으로 구성된 복수평면 재구성(multi-planar reconstruction; 이하 MPR) 화면을 기본으로 하며, 표면 렌더링 또는 볼륨렌더링 기법으로 구성된 3차원 이미지도 제공된다. 일반적으로 3차원 영상은 의 료영상을 이용해 재구성된 화면으로 흑백 또는 색깔을 입힌 컴퓨터 그래픽으로 표현된다. 본 기고 에서 중점을 두고 있는 증강현실 내비게이션의 경우, 실제 환부를 보여주는 카메라 영상을 사용하 며, 이 카메라 영상 위에 의료영상에서 재구성된 그래픽 객체가 중첩되어 표시되는 형태이다. 앞 서 언급한 바와 같이 증강현실을 이용하기 위해서는 카메라 영상과 그래픽 객체간의 위치 관계를 정의하는 기술이 별도로 필요하다. 관련해서는 다음 장에서 설명한다.

\section{수술에서 증강현실의 응용}

앞서 의료영상이 진단뿐 아니라 수술에 직접 사용될 수 있고 이를 수술내비게이션이라 함을 언 급했다. 수술에 따라 증강현실 기법을 이용하여 보다 효과적인 수술내비게이션을 구현할 수 있다. 증강현실을 사용하지 않는 기존의 수술내비게이션의 경우, 문제점 중 하나는 수술 중 내비게이션 정보를 확인하고 싶을 때 수술 부위에서 시선을 돌려 내비게이션 화면을 바라보아야 한다는 것이 다. 또는 별도의 인원이 내비게이션 화면을 확인하면서 집도의에게 구두로 설명을 해 주어야 한 
다. 비록 잠깐의 순간이지만 수술을 하면서 환부에서 시선을 돌려 다른 곳을 바라본다는 것은 바람 직하지 않다. 마치 운전을 하면서 내비게이션 화면을 보는 순간, 전방을 온전히 주시할 수 없는 것 과 같다. 그래서 때로는 음성으로만 내비게이션 정보를 얻는다. 하지만 수술내비게이션의 경우는 오직 음성으로만 정보를 전달하기는 용이하지 않다. 환부의 위치나 모양, 접근 방법 등이 도로와 같이 정형화되어 있지 않기 때문이다.

만약 수술 부위에서 눈을 떼지 않고 부가적으로 수술내비게이션 정보를 활용할 수 있다면 큰 장 점이 될 수 있다. 증강현실 내비게이션은 수술 부위를 직접 보여주는 카메라 영상을 기본으로, 카 메라 영상 위에 부가 정보를 표시하기 때문에 수술부위를 항상 관찰할 수 있는 장점이 있다(1-3). 특히 여러 내시경이나 수술현미경을 사용하는 수술의 경우 카메라 화면을 보면서 수술을 진행하 므로, 증강현실을 이용한 수술내비게이션의 장점을 살릴 수 있다. 내시경 화면, 또는 현미경 화면 에 부가 정보로서 장기 안의 보이지 않는 혈관이나 신경을 3차원 그래픽으로 재구성하여 표시할 수 있다. 따라서 집도의가 수술 중에 내시경이나 현미경 화면에서 눈을 떼는 일 없이 기존 방식 그 대로 수술을 계속할 수 있다(Fig. 2).

증강현실을 이용한 수술내비게이션은 이미 의료현장에서 사용되고 있고, 많은 연구들이 수행되 어 왔다(4). Medtronics나 BrainLab 등 상용 수술내비게이션 시스템에서는 현미경 화면 위에 특 정 조직을 윤곽으로 표시하는 기능을 가지고 있다. 하지만 도입비용이 높고 충분한 성능을 보이지 않아 널리 사용되고 있지 않은 것으로 보인다. 또한 학계에 보고되는 증강현실 이용 사례도 아직 은 드물다. 보다 많은 보급과 사용을 위해 연구 개발의 필요성이 있다. 기존의 MPR 영상을 이용한 수술내비게이션이나 $3 \mathrm{D}$ 그래픽을 이용한 시스템보다 카메라의 도입으로 시스템이 더욱 복잡해지 고 여러 단계의 좌표 변환을 거쳐야하므로 더 정확하고 신뢰성 있는 증강현실 시스템의 개발이 필 요하다. 증강현실 시스템을 구성하는 요소들과 기존의 수술내비게이션과의 차이점 등은 다음 절 에서 설명하기로 한다.

증강현실을 수술에 이용한 연구들 중 대표적인 사례를 소개하면 다음과 같다.

북경대학의 한 연구팀은 부비동 수술을 지원하는 증강현실 시스템을 개발했다(5). 부비동(sinus)과 두개저(skull base) 수술에서 수술자는 비강에 삽입된 내시경 화면에 의존하여 수술을 한 다. 비강에 삽입되는 내시경은 매우 좁은 시야각을 가지고 있기 때문에 내시경 영상만으로 환부의 정확한 위치를 파악하기 어렵다. 본 연구에서는 비강 내 구조물들을 가상환경에서 복원하고, 복원

Fig. 2. Surgical navigation using virtual reality (A) and augmented reality (B).
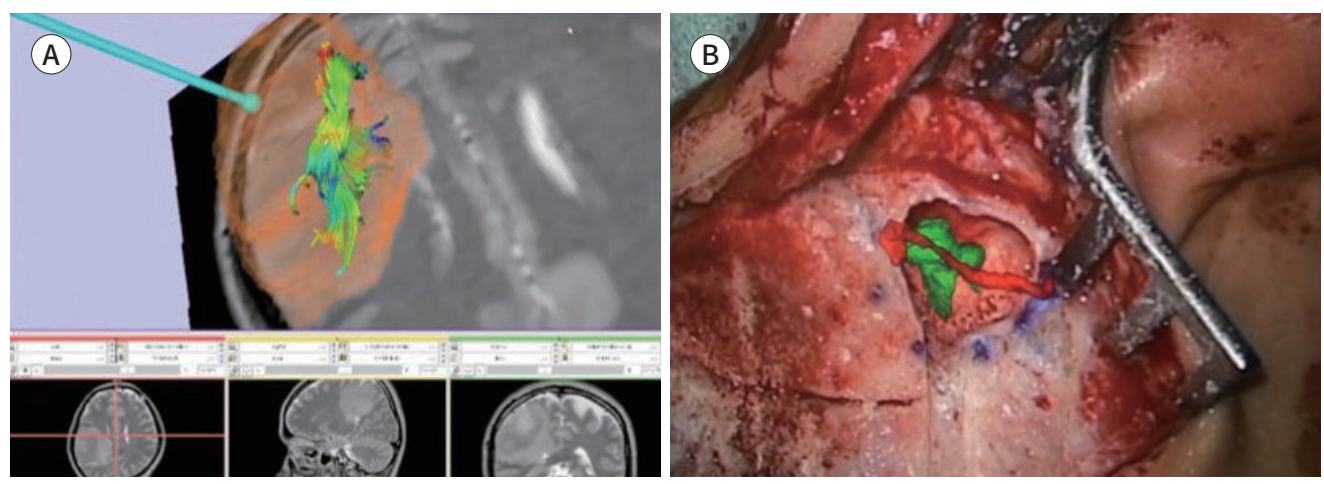
된 구조물을 내시경 화면에 정렬시켜 중첩표시 하였다. 결과적으로 수술자는 기존 내시경 화면뿐 아니라 내시경 화면 밖의 비강 구조물도 인지할 수 있게 된다. 즉, 증강현실 기술을 사용하여 기존 내시경의 좁은 시야각을 넓히는 효과를 낸 것이다. 사체 실험을 통해 평균 $1.28 \mathrm{~mm}$ 의 오차를 보 였고, 수술 시간도 기존 수술 내비게이션에서보다 16 초가량 감소했다고 보고했다.

한편, 초음파영상기반 유방조직검사에서 수술자는 초음파영상을 보면서 양손으로 초음파 프로 브와 생검용 바늘을 조작해야 한다. 이 과정에서 수술자에게는 눈으로 보는 시각 정보와 손의 움 직임을 조율하는 능력(hand-eye coordination)이 크게 요구된다. 노스캐롤라이나 대학에서는 직 시형 헤드마운트디스플레이(video-see through HMD) 기반 증강현실을 사용하여 빠르고 정확한 바늘생검을 가능하게 하는 시스템을 개발했다(6). 외부 위치추적센서를 이용해 초음파 프로브, 생 검용 바늘, $\mathrm{HMD}$ 의 위치를 추적하고, 이를 이용하여 초음파영상과 삽입된 생검용 바늘의 위치를 실제 $\mathrm{HMD}$ 영상 위에 중첩하여 표현하였다. 결과적으로 $\mathrm{HMD}$ 를 착용한 의사는 시선을 돌려 초음 파영상 모니터를 확인할 필요 없이 환부에 시선을 그대로 두고도 생검용 바늘의 삽입 방향 및 위 치를 초음파 영상을 참고로 실시간으로 파악할 수 있다.

동경대학의 한 연구팀은 integral videography (이하 IV) 기술을 응용한 수술용 증강현실을 개 발하였다(7). IV 기술로 만들어진 3D 오브젝트를 환부 위에 놓여진 반투명 거울에 반사시켜 실제 환부 위에 $3 \mathrm{D}$ 오브젝트가 중첩 표시되도록 하였다. $\mathrm{HMD}$ 시스템에 불편을 느끼고 저항감이 있는 시술자가 호감을 느낄 수 있는 디스플레이 방식으로, 시술자는 머리에 쓰는 장치 없이도 반투명 거 울을 통해 증강된 가이드 정보를 참조할 수 있다. 바늘삽입 테스트를 통해 시스템의 정확성을 검증 하였고 평균 오차가 $2.6 \mathrm{~mm}$ 로 보고되었다.

뮌헨공과대학(Technical University of Munich)에서는 C-arm과 RGB 카메라를 결합시켜 RGB 카메라 영상 위에 X-ray 영상을 중첩표시하는 증강현실 시스템을 개발했다(8). 정형외과에서 시행 하는 골수내정고정술(intramedullary nail locking)에서 골수강에 삽입된 nail과 locking을 위해 사용하는 도구의 상대적 위치를 파악하기 위해 X-ray 촬영을 시행하는데, 정확한 3차원적인 위치 관계를 보여주기 어려워 반복적으로 X-ray 촬영을 하게 되고 이는 환자와 수술자의 방사선 노출을 증가시키는 원인이 되어왔다. 캘리브레이션으로 정렬된 두 대의 카메라를 이용해 구현된 증강현 실을 이용하여, $1 \mathrm{~mm}$ 이내의 영상 중첩의 오차를 보여주었고 시술 시 X-ray 촬영 횟수를 줄일 수 있었다.

\section{증강현실의 구성요소}

수술 중에 의료영상을 사용하기 위해 기본적으로 환자-영상 정합과정이 필요하다. 이는 환자 좌 표계와 의료영상 좌표계사이의 관계를 정의하는 것으로, 결과로서 변환행렬이 구해진다. 여기에 다 환자 좌표계를 정의하고, 환부와 수술도구의 움직임을 실시간으로 추적하는 위치추적센서가 갖춰지면 수술내비게이션의 기본적인 시스템은 구성된다. 즉 환자, 의료영상, 위치추적장치, 컴퓨 터와 디스플레이가 기존의 수술내비게이션 시스템의 기본 구성요소라고 할 수 있다. 이 중에 도입 비용이 높은 것은 단연 위치추적센서이다. 
위치추적센서는 크게 광학식과 전자기식으로 나누어진다. 광학식은 다시 가시광선을 사용하는 방식과 적외선을 사용하는 방식으로 나뉜다. 성능은 큰 차이가 나지 않지만 적외선을 사용하는 방 식이 훨씬 더 많이 사용되고 있다. 광학식 위치추적장치는 대개 $0.2 ~ 0.3 \mathrm{~mm}$ 정도의 정밀도를 가 지는데, 이는 보통 수 $\mathrm{mm}$ 단위의 환자-영상 정합 오차를 고려하면 충분한 성능이다. 즉 위치추적 센서를 더 정밀하게 만드는 것은 수술내비게이션의 최종적인 정확도를 높이는 데 있어 크게 기여 하지 않는다고 볼 수 있다. 다만 광학식 위치추적장치의 가장 큰 문제점은 센서 위치에 따른 인식 불능 문제인데, 위치추적센서로 사용되는 카메라는 전용 위치추적 마커를 항상 인식할 수 있는 위 치와 방향으로 있어야 한다. 마커는 환부나 수술도구에 부착되는데, 이 마커와 카메라 사이를 사 람이나 물체가 가로막고 있으면 위치 인식이 불가능하다. 많은 인원과 장비들이 위치하는 좁은 수 술실에서 이와 같은 위치센서(카메라)의 광선 차단 문제는 흔히 발생하며, 카메라의 위치와 마커 의 위치를 어디에 둘 것인가가 항상 고민스러운 문제가 된다.

반면 전자기식 위치추적센서는 자기장 발생장치과 이에 반응하는 센서로 구성된 시스템으로 광 학식 위치센서의 카메라에 해당하는 자기장 발생 장치와 광학식위치추적 센서의 마커에 해당하 는 자기장센서 사이에 사람이나 물체가 위치해도 그것이 자기장을 차단하는 금속성 물체가 아니 라면 문제없이 동작한다. 따라서 인체 내부에 삽입되는 카테터나 바늘, 내시경 등에 이와 같은 자 기장센서를 부착하여 인체 내부에 있는 수술도구의 위치를 알아낼 수 있다(9). 한편, 광학식 위치 추적장치를 사용하는 경우는 인체 내부에 삽입되는 수술도구의 반대쪽 끝, 즉 인체 외부로 노출되 는 부위에 마커를 고정해야 하며, 수술도구가 강성이 있어 굽거나 휘지 않는다는 전제가 필요하 다. 카테터나 바늘 같은 수술도구에는 일반적으로 부착이 어렵다. 이처럼 광선 차단 문제를 피할 수 있고, 인체 내부에 삽입되는 수술도구, 휘거나 굽거나 변형이 일어나도 사용할 수 있는 전자기 식 위치추적센서의 장점이 훨씬 큰 것 같으나 여기에도 문제점이 있다. 우선 광학식 위치추적장치 에 비해 상대적으로 떨어지는 정밀도이다. 최근에는 정밀도가 향상되어 수술내비게이션에 사용하 기에 충분한 전자기식 위치추적장치들이 판매되고 있지만 아직 광학식 위치추적센서가 더 신뢰 받고 있다. 또 다른 중요한 차이점은 전자기식의 경우 동작 범위가 광학식에 비해 좁다는 것이다. 따라서 복부와 같이 비교적 넓은 영역을 다루어야 하는 수술에는 적합하지 않고 이비인후과나 신 경외과와 같이 수술부위가 작은 경우에 사용되고 있다. 또 다른 문제점은 자기장을 간섭하는 종류 의 금속 물질 사용이 제한된다는 점이다. 그리고 광학식 위치추적장치의 경우 빛의 반사를 이용하 므로 무선으로 마커를 환부나 수술도구에 부착하여 사용할 수 있지만, 전자기식의 경우 센서에 전 류를 공급해야 하므로 반드시 유선 연결이 필요하다.

환자와 의료영상, 그리고 위치추적장치까지는 증강현실을 사용하지 않는 기존의 수술내비게이 션에도 공통된 요소이다. 그러나 증강현실을 이용하는 경우에는 카메라가 추가로 필요하다. 카메 라는 실물을 촬영하기 위한 목적으로 주로 사용되지만 때로는 위치추적센서로 사용되거나, 이 둘 의 기능을 겸하기도 한다. 카메라로 촬영된 영상을 표시하기 위해 디스플레이 장치도 마땅히 필요 하다. 이처럼 증강현실에서 카메라와 디스플레이는 실물(환자)을 인식하고 실물과 가상의 정보를 표시하는데 사용된다. 때로는 카메라와 디스플레이 대신 $\mathrm{HMD}$ 를 사용하기도 하고, 프로젝터를 사용해서 실물 위에 가상의 정보를 직접 투사 표시하기도 한다. 어느 경우든 실물을 인식하고, 실 
물과 가상의 물체 또는 정보를 표시하는데 사용되는 장치들이다. 본 논문에서는 카메라와 디스플 레이를 대표적인 장치로 언급하겠다. 앞서 말한 것처럼, 내시경이나 수술현미경을 사용하는 경우 이 장비들이 곧 카메라의 역할을 수행한다. 따라서 별도의 카메라 없이 증강현실 시스템을 구현할 수 있는 이점이 있다.

카메라의 등장으로 증강현실 시스템은 훨씬 복잡해지는데, 외부위치추적센서의 유무에 따라 증 강현실 시스템을 다시 세분하는 것은 여기서 생략하고, 본 기고에서는 기존의 위치추적장치를 그 대로 사용하면서 카메라를 추가로 사용하는 방식을 설명하기로 한다. 증강현실은 결과적으로 카 메라로 획득하는 실물 영상 위에 가상의 물체 또는 정보를 정확한 위치와 크기로 표시하는 것이 다. 여기서 가상의 물체와 정보들이라 함은 카메라 영상에는 보이지 않는 장기 내부의 종양이나 혈관, 신경 등을 가리킨다. 물론 이 조직들은 실제 존재하는 것들로 가상의 물체가 아니지만, 카메 라 영상이나 육안으로는 보이지 않는 것이기에 여기서 가상의 물체로 간주한다. 이러한 가상의 물 체(내부 구조물) 들은 CT와 같은 의료영상에서 추출해 낼 수 있고, 실제 영상 위에 표시하는 부가 적인 정보로 종양까지의 거리나 각도 등을 표시할 수도 있다(10).

아래 수식 1)은 증강현실 시스템을 구현하기 위해 필요한 기본적인 계산을 나타내는 식으로 $\mathrm{T}_{\mathrm{I}}^{\mathrm{C}}$ 는 카메라 영상 위에 의료영상에서 추출한 가상의 물체(종양, 혈관 등)를 어떻게 표시할 것인가를 정의하는 변환행렬이다. 보는 바와 같이 여러 개의 변환행렬의 곱으로 정의된다. 반면 기존의 카 메라를 사용하지 않는 3D 그래픽 기반의 수술내비게이션의 경우는 수식 2)와 같이 표현될 수 있 다. 여기에서는 최종 행렬이 $\mathrm{T}_{\mathrm{D}}^{\mathrm{I}}$ 로 의료영상 위에 현재 수술도구의 위치를 나타내기 위한 것이다.

1) $T_{I}^{C}=T_{C M}^{C} T_{O}^{C M} T_{P}^{O} T_{I}^{P}$

2) $\mathrm{T}_{\mathrm{D}}^{\mathrm{I}}=\mathrm{T}_{\mathrm{P}}^{\mathrm{I}} \mathrm{T}_{\mathrm{O}}^{\mathrm{P}} \mathrm{T}_{\mathrm{D}}^{\mathrm{O}}$

$\mathrm{T}_{\mathrm{O}}^{\mathrm{CM}}, \mathrm{T}_{\mathrm{P}}^{\mathrm{O}}$ 위치추적 센서 출력값, $\mathrm{T}_{\mathrm{I}}^{\mathrm{P}}$ 영상 정합결과 행렬, $\mathrm{T}_{\mathrm{CM}}^{\mathrm{C}}$ 위치센서 카메라 정합 결과 행렬

\section{증강현실 수술내비게이션의 과제들}

앞서 기술한 기본 구성요소들을 이용해서 수식 1)과 같은 연산을 수행하면 증강현실 시스템을 구현할 수 있다. 하지만 이와 같은 증강현실 시스템을 의료에 사용하기 위해서는 극복해야 할 과 제들이 있다. 우선 안정된 정확도의 확보이다.

정확도라 함은 수식 1)의 $\mathrm{T}_{\mathrm{I}}^{\mathrm{C}}$ 를 얼마나 정확하게 계산하는가를 의미한다. $\mathrm{T}_{\mathrm{I}}^{\mathrm{C}}$ 를 결정하는 요소들 은 $\mathrm{T}_{\mathrm{CM}}^{\mathrm{C}}, \mathrm{T}_{\mathrm{O}}^{\mathrm{CM}}, \mathrm{T}_{\mathrm{P}}^{\mathrm{O}}, \mathrm{T}_{\mathrm{I}}^{\mathrm{P}}$ 들인데, 이 중 $\mathrm{T}_{\mathrm{O}}^{\mathrm{CM}}, \mathrm{T}_{\mathrm{P}}^{\mathrm{O}}$ 는 위치추적센서의 출력 값들로 위치추적센서의 성능 에 의존한다. 앞서 언급한 바와 같이 현재 사용되는 위치추적 장치의 정밀도가 $0.2 ~ 0.3 \mathrm{~mm}$ 정도 로 최종 오차에 주는 영향은 크지 않다고 할 수 있다. 나머지 두 요소 중 먼저 $\mathrm{T}_{\mathrm{I}}^{\mathrm{P}}$ 를 살펴보면 이는 환자-영상 정합 결과를 나타내는 변환행렬이다. 이 변환행렬은 증강현실뿐 아니라 기존의 전통적 인 수술내비게이션의 정확도를 결정하는 변환행렬이기도 하다.

환자-영상 정합의 정확도에 영향을 주는 요인들은 많다. 예를 들어 환자 피부에 부착하는 피부 마커의 좌표를 정확히 얻지 못하는 것이 원인이 되기도 한다. 이는 피부마커의 이동이나 손실이 
원인이 되기도 하지만, 사용자에 따라 수술 중에 포인팅해서 얻는 좌표 값에 차이가 난다. 이 마커 들이 영상에서 얼마나 잘 인식되느냐도 정합 결과에 영향을 주는 중요한 요인이다(11). 영상 왜곡 은 차치하더라도 마커가 잘 보이지 않거나 보여도 정확히 마커의 중앙 좌표를 획득하는 것은 쉽지 않다. 이외 여러 가지 원인들이 있을 수 있다. 피부마커 대신에 해부학적인 특징점을 사용하고 이 를 병용하기도 한다. 또한 템플릿 방식의 정합을 수행하기도 한다 $(12,13)$. 각각의 방법에는 장점 과 단점이 있다.

현재 임상에서 가장 흔하게 사용되는 영상 정합법은 피부마커나 해부학적 특징점으로 대략의 정 합을 하고 iterative closest point (이하 ICP)라 불리는 방법을 이용해 환자 피부의 윤곽과 의료영 상의 대응 부위 간 면대면(surface to surface) 정합을 시도하는 것이다. 여러 가지 시도에도 불구 하고 여전히 안정적이고 정확한 $\mathrm{T}_{\mathrm{I}}^{\mathrm{P}}$ 를 얻는 것은 어려운데, 대표적인 원인으로서 변환행렬을 구하 는 과정에서 국소 최소값(local minimum)에 빠지는 문제이다. 수식 3)의 Fiducial Registration Error (이하 FRE)를 최소로 하는 변환행렬 $\mathrm{T}$ 가 $\mathrm{T}_{\mathrm{I}}^{\mathrm{P}}$ 인데, $\mathrm{ICP}$ 와 같은 방법에서 특히 초기치에 민감 하게 최소국소값에 빠지는 경우가 있다. 이마나 볼과 같이 밋밋한 부위를 이용하여 정합을 수행하 면 이런 위험성이 증가하기에 콧등이나 눈 주위 입술과 귀 등 특징이 많은 부위를 사용하는 것이 높은 정확도를 얻을 수 있는 요령이다. 또 한 가지 정확도를 떨어뜨리는 이유는 대부분의 경우 정 합이 피부에 부착하는 마커 또는 피부의 굴곡이나 형상을 이용하기 때문에 피부를 지나 실제 종양 이나 혈관과 같이 신체 내부의 수술부위에 도달했을 때 많은 오차가 발생하게 된다. 이를 방지하 기 위해서는 피부의 특징점만 사용하지 않고 인체 내부의 특징점을 동시에 활용하는 방법이 있다 $(14,15)$. 초음파 또는 X-ray를 이용해서 인체 내부의 특징점을 얻어내어 이를 정합 결과에 반영시 키면 비록 FRE는 커지더라도 Target Registration Error (이하 TRE)는 작은 정합 결과를 얻을 수 있다(Fig. 3). 여기서 FRE는 정합에 사용한 특징점을 이용하여 구한 이론적 정합 오차를, TRE는 실 제 수술목표 부위에서 측정한 정합 오차를 의미한다. 특히 의료진에 의해서 수술내비게이션 시스 템이 운용되는 경우, 의료진은 FRE만 보고 수술내비게이션의 정확도를 과신할 우려가 있다. 하지 만 국소 최소값에 갇혀서 FRE가 적게 나타날 수도 있으며, 피부표면에서 FRE가 작더라도 수술이 진행되어 환부에 가까이 갔을 때 오차가 크게 발생하는 경우도 있으므로, FRE 수치에 의존하지 않고 비록 FRE가 커지더라도 보다 나은 TRE를 얻을 수 있는 정합 방법을 취해야 한다. 이를테면 이비인후과의 경우 한쪽 귀 주위의 마커만 이용하는 것 보다 눈이나 코 주변의 특징점을 이용할 경우 FRE는 오히려 증가할 수 있으나 내부의 특정 위치에서 보다 작은 TRE를 얻기도 한다. 그러

Fig. 3. Skin markers cause large target registration error in spite of small fiducial registration error. Target represents a tumor in axial images.

Skin markers $\begin{array}{ccc}\text { Patient } \\ \text { body }\end{array}$


므로 정합 오차에 대한 정확한 이해와 신중한 접근법이 필요하다고 할 수 있다.

여기까지는 증강현실을 포함한 일반적인 수술내비게이션의 정확도를 결정하는 환자-영상 정합 정확도에 관련된 이슈들을 언급했다. 다음으로 증강현실을 사용할 경우에만 고려되는 오차의 원 인이 있는데, 바로 $\mathrm{T}_{\mathrm{CM}}^{\mathrm{C}}$ 이다. 이는 카메라-위치추적마커 간의 정합 정밀도라고 볼 수 있으며, 좀 더 단순하게 카메라-위치추적센서 캘리브레이션이라고 말할 수도 있다. 기술적으로는 핸드-아이 (hand-eye) 캘리브레이션 과정에 해당한다. 로보틱스에서 로봇팔에 카메라가 부착된 경우 로봇팔 과 카메라 사이의 캘리브레이션을 가리켜 핸드-아이 캘리브레이션이라고 한다. 증강현실의 경우 로봇팔은 없지만 위치추적센서가 로봇팔의 역할을 한다고 볼 수 있다. 따라서 문헌에서는 기술용 어인 핸드아이 캘리브레이션을 그대로 사용하기도 한다. 하지만, 증강현실에서 특히 수술용 증강 현실에서는 카메라-위치추적센서 정합이라고 일컫는 것이 더 정확한 표현이라고 생각되어 본 기 고에서는 이 용어를 사용하겠다. 우선 카메라가 증강현실 시스템에서 필수적인 요소인 것은 앞서 서술했다. 그러면 위치추적센서와 카메라 사이에 정합이 필요한 이유는 무엇인가? 카메라와 카메 라가 촬영하는 대상이 서로 움직일 수 있기 때문이다. 둘 중 하나 또는 둘 다 실시간으로 움직일 수 있기 때문에 이 둘 사이의 위치관계를 알아내기 위해서는 위치추적센서의 마커가 카메라에 부착 되어 있어야 하고 촬영하는 대상(여기서는 환자)에도 부착되어 있어야 한다. 그리고 카메라의 좌표 계와 위치추적센서 마커가 정의하는 좌표계 사이의 정합이 필요하다. 위치추적센서 마커의 좌표계 는 마커가 특정 형상을 가지고 육안으로 확인되기 때문에 직관적으로 정의되거나 측정될 수 있다. 하지만 카메라의 좌표계는 보이지 않으며 카메라의 형상으로 추정하기 어렵다. 그렇기 때문에 특 별히 카메라-위치추적센터 캘리브레이션 과정을 통해 이 관계를 알아내게 된다. 다만 위치센서는 센서용 카메라로부터 멀어질수록 성능이 떨어지는 경향이 있다. 또한 사람이 카메라를 직접 움직 이며 캘리브레이션을 수행하는 과정에서 손떨림 등의 영향을 받을 수도 있다. 따라서 얼마나 정확 한 카메라-위치추적센서 정합을 수행하느냐의 문제는 잘 알려진 환자-영상 정합 문제와 함께 증강 현실 시스템의 정확도를 결정하는 중요한 요소로 이 성능을 향상시키는 연구들이 수행되어 왔다 $(16,17)$.

3) $F R E=\sqrt{\left(\frac{1}{n} \sum_{j=1}^{n}\left|T i_{j}-p_{j}\right|^{2}\right)}$

Fiducial Registration Error (FRE), $\mathrm{i}_{\mathrm{j}} \mathrm{j}$ 번째 특징점의 영상좌표, $\mathrm{p}_{\mathrm{j}} \mathrm{j}$ 번째 특징점의 환자 좌표

증강현실의 또 다른 과제는 부족한 깊이감의 표현 문제이다. 증강현실은 실제 환부를 보여주는 내시경 또는 현미경 영상 위에 직접적으로 부가적인 종양이나 혈관의 모습을 표시할 수 있다는 장 점이 있지만, 실제로는 장기 내부에 위치하는 조직들이 오히려 장기 위에 떠 있는 형태로 표시된 다. 실제 표시되는 조직들이 어느정도 깊이에 위치하는지 가늠하기는 어렵다. 오히려 기존의 3차 원 그래픽을 이용하는 수술내비게이션의 경우는 사용자가 임의로 시점을 바꾸고 확대, 축소할 수 있어서 표시되는 조직들간의 거리를 쉽게 알 수 있다. 이러한 깊이감 문제를 해결하기 위한 연구 로서 3차원 그래픽과 증강현실 뷰를 전환하여 표시하는 기능이 제안되었다(2). 이 기능을 이용하 면 평소 증강현실 내비게이션을 이용하다가 필요시 3 차원 가상 공간으로 전환하여 조직들간의 상 
호관계를 확인할 수 있다. 또한 중요한 조직까지의 거리나 각도를 안내선과 함께 수치로 표시해 줌으로써 2차원 영상의 부족한 깊이감을 보완할 수 있다(18) (Fig. 4).

\section{증강현실 수술내비게이션의 응용}

증강현실 시스템을 이용한 사례를 몇 가지 소개하면 다음과 같다.

\section{골종양 수술}

기존의 골종양의 수술의 경우, 종양의 위치를 확인하기 위해서 수술 중에 C-arm 등을 이용한 X-ray 영상을 필요로 했다. 하지만 환자는 물론 시술하는 의사도 많은 양의 방사선에 노출되는 문 제가 있다. 투시 영상 대신 증강현실 시스템을 이용하면 육안으로 볼 수 없는 종양의 위치를 3차원 공간에서 확인할 수 있다(19). 이를 이용해 제거할 부위를 수술 전에 마킹할 수 있고, 절제용 수술 기구에 위치추적센서용 마커를 부착할 수 있다면 절제 범위뿐 아니라 톱날의 각도까지 유도할 수 있다(1). 또한 이 시스템은 위치추적센서 없이 휴대용 스마트 기기에 내장된 카메라를 위치추적센 서로 활용하여 구현할 수 있다. 다만 이 경우 빠른 처리 속도나 높은 정밀도를 얻기에 어려움이 있 으나 필요한 순간에만 내비게이션을 사용한다고 했을 때 임상에서 사용이 가능하다(Fig. 5).

\section{악안면 교정 수술}

기존의 악교정 수술의 경우, 미간에 고정하는 나사못 기준점과 치아의 특징점을 사용하여 수술 전에 계획한 대로 악교정이 이루어지는지를 확인하므로 직관적이지 않고 오차가 발생하기도 하 였다. 증강현실 기법을 이용하여 X-ray를 사용하지 않고도 절단한 턱뼈의 3차원적인 위치나 각도 를 직관적으로 확인할 수 있어 수술에 응용될 수 있다. 또한 이러한 기법은 치과영역에도 적용될 수 있어 임플란트 시술에서 임플란트의 삽입 각도나 깊이를 유도할 수 있다. 이러한 악안면 수술 또는 치과수술의 경우 좁은 영역에서 시술이 이루어지기 때문에 위치추적센서용 마커를 부착하 는 것이 어려운 문제가 될 수 있다. 기존의 상용 위치추적센서의 경우 마커 크기가 보통 장축 $5 \mathrm{~cm}$ 이상 되기 때문에 환부에 고정하거나 수술도구에 고정하기에 부담이 된다. 따라서 소형, 경량의 마커가 개발된다면 수술내비게이션의 적용이 더 용이해질 것으로 예상된다. 치과 및 악안면의 경

Fig. 4. Depth information is provided in quantity at lower left corner, and background color (yellow) shows the level of potential risk.

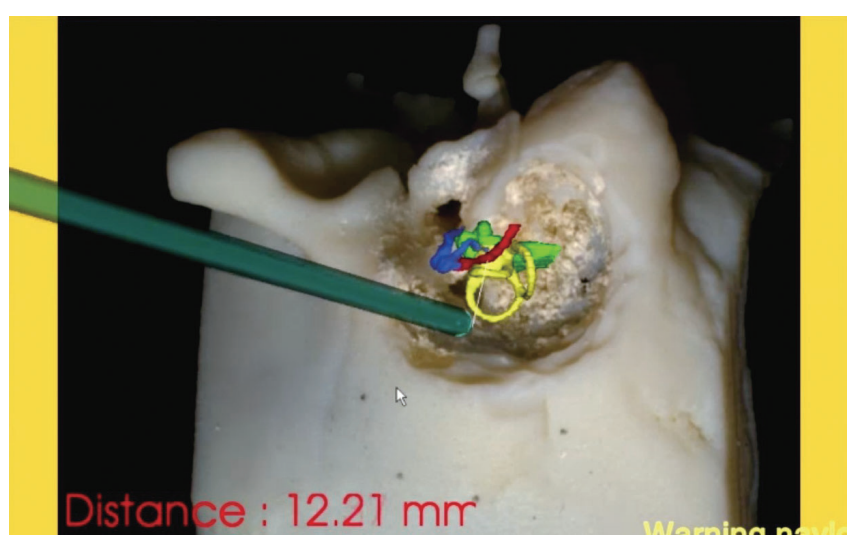


Fig. 5. Augmented reality for bone tumor resection.

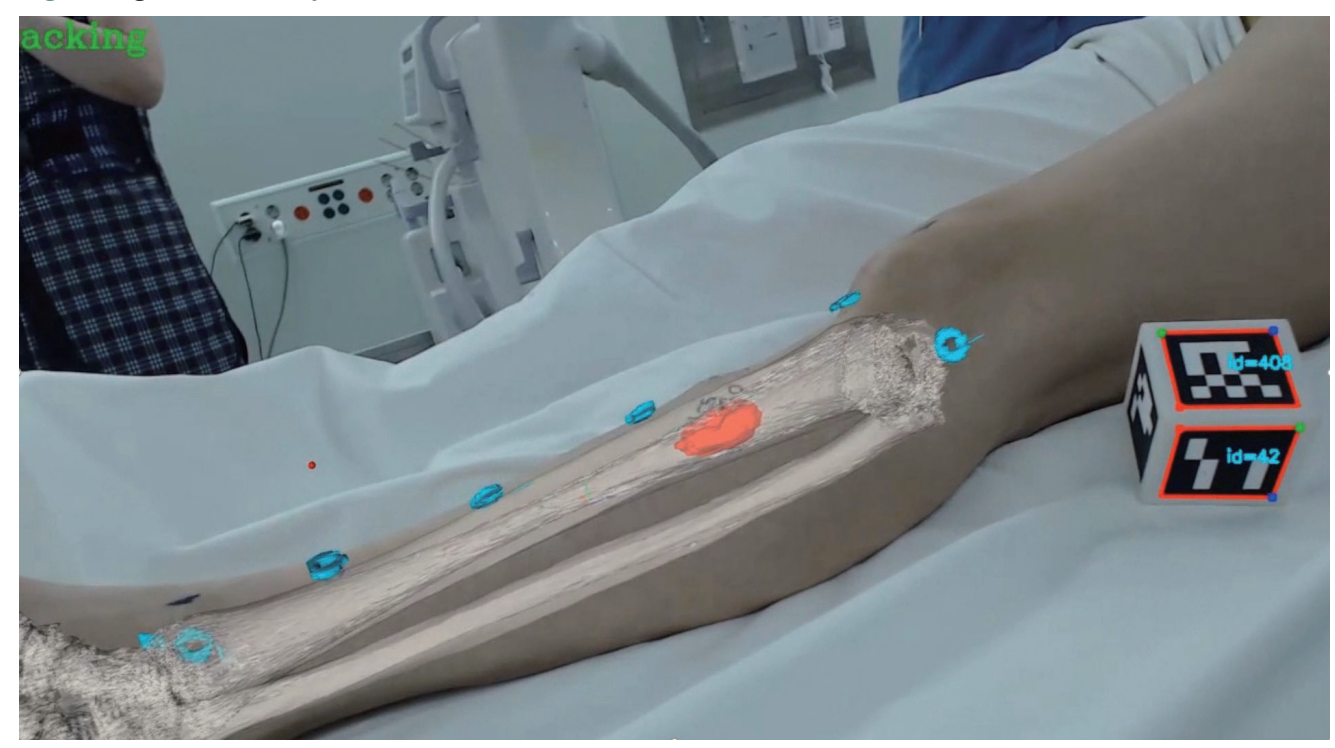

우 윗니와 아랫니의 형상이나 특징점을 이용한 환자-영상 정합이 가능하며, 환부를 추적하는 레퍼 런스 마커 또한 윗니와 아랫니를 이용하여 고정할 수 있기 때문에 다른 수술부위에 비해 정확한 영상유도가 가능하다.

\section{심근경색 치료를 위한 심장 카테터 시술}

내시경과 같은 카메라 영상을 사용하지 않기 때문에 다소 성격이 다르다고 할 수 있으나, 동일한 증강현실 기법을 이용하여 심장 카테터 시술을 지원할 수 있다. 기존에는 2차원 C-arm 영상에 의존 하여 시술하면서 깊이 정보의 결여로 인해 혈관의 3차원 형상을 정확하게 파악하지 못하고 카테터 의 유도가 어려운 경우가 있었다. 하지만, 시술 전의 3차원 CT 영상을 시술 중의 2차원 X-ray 영상 과 정합하여 혈관의 위치와 형태를 입체적으로 파악하고 카테터의 정확한 유도를 지원할 수 있다. 이 경우 X-ray 영상이 카메라와 같이 실물을 보여주는 영상에 해당되고, CT 에서 추출한 병변이나 혈관의 3차원 정보가 실물 위에 표시될 가상의 물체에 비교된다. 이와 같은 내비게이션을 이용해 기존의 C-arm 사용 빈도와 시간을 줄임으로써 시술자와 환자의 방사선 노출을 줄일 수 있다.

이와 같은 증강현실 내비게이션을 구현하기 위해서는 C-arm 장비의 긴 초첨거리에 대응하는 새로운 카메라 캘리브레이션 기법이 필요하며, C-arm 광원의 광학 특성을 파악하고(20) 위치센서 또는 C-arm의 기구학 정보를 활용하여 카메라-위치추적센터 캘리브레이션을 수행하므로 순수 영 상정보만을 이용하는 경우에 비해 훨씬 빠른 2D-3D 영상정합을 수행할 수 있다.

\section{결론 및 전망}

앞으로 의료영상은 진단뿐 아니라 수술을 지원하기 위해 적극 활용될 것이다. 특히 내시경이나 수술현미경을 사용하는 수술의 경우 증강현실 기법은 효과적인 수술내비게이션의 대안이 될 수 있다. 다만 환자-영상 정합이나 카메라 위치센서 정합과 같은 기술의 뒷받침이 필요하며, 위치추 
적센서를 대체하는 카메라 관련 기술 등이 필요하다. 수술 전 세팅 시간이나 설치 및 사용의 복잡 도는 수술내비게이션 시스템의 보급에 있어 중요한 문제가 된다. 기존 상용시스템의 경우 설치 시 간이나 준비의 번거로움, 안정되지 않는 정합 정확도 등으로 인해 아직까지 전반적인 도입과 사용 이 이루어지지 않고 있다. 하지만 향후 기술의 발전에 힘입어 보다 많은 병원, 보다 많은 수술에서 적용이 확대될 것으로 예상된다.

또 한 가지 기술적인 과제로서 비단 증강현실 내비게이션 시스템에 국한되지 않는 것이지만 연 조직의 변형이나 이동 문제가 있다. 현재까지 사용되고 있는 수술내비게이션도 대부분 이동 및 변 형이 적은 경조직을 대상으로 하고 있다. 하지만 연조직의 변화를 효과적으로 다룰 수 있는 기술 이 개발된다면 임상에서의 적용이 한 단계 더 확대될 수 있다. 증강현실을 비롯한 수술내비게이션 의 발전은 수술 중 X-ray 영상의 사용을 줄이는 효과를 가져올 수 있으며, 이 한 가지 특성만으로 도 환자와 의료진이 받는 혜택은 충분히 크다고 할 수 있을 것이다.

\section{Conflicts of Interest}

The author has no potential conflicts of interest to disclose.

\section{REFERENCES}

1. Choi H, Park Y, Lee S, Ha H, Kim S, Cho HS, et al. A portable surgical navigation device to display resection planes for bone tumor surgery. Minim Invasive Ther Allied Technol 2017;26:144-150

2. Choi H, Cho B, Masamune K, Hashizume M, Hong J. An effective visualization technique for depth perception in augmented reality-based surgical navigation. Int J Med Robot 2016;12:62-72

3. Kim S, Hong J, Joung S, Yamada A, Matsumoto N, Kim SI, et al. Dual surgical navigation using augmented and virtual environment techniques. Int J Optomechatroni 2011;5:155-169

4. Inoue D, Cho B, Mori M, Kikkawa Y, Amano T, Nakamizo A, et al. Preliminary study on the clinical application of augmented reality neuronavigation. J Neurol Surg A Cent Eur Neurosurg 2013;74:71-76

5. Li L, Yang J, Chu Y, Wu W, Xue J, Liang P, et al. A novel augmented reality navigation system for endoscopic sinus and skull base surgery: a feasibility study. PLoS One 2016;11:e0146996

6. Rosenthal M, State A, Lee J, Hirota G, Ackerman J, Keller K, et al. Augmented reality guidance for needle biopsies: an initial randomized, controlled trial in phantoms. Med Image Anal 2002;6:313-320

7. Liao H, Hata N, Nakajima S, Iwahara M, Sakuma I, Dohi T. Surgical navigation by autostereoscopic image overlay of integral videography. IEEE Trans Inf Technol Biomed 2004;8:114-121

8. Navab N, Heining SM, Traub J. Camera augmented mobile C-arm (CAMC): calibration, accuracy study, and clinical applications. IEEE Trans Med Imaging 2010;29:1412-1423

9. Jeon S, Lee GW, Jeon YD, Park IH, Hong J, Kim JD. A preliminary study on surgical navigation for epiduroscopic laser neural decompression. Proc Inst Mech Eng H 2015;229:693-702

10. Cho B, Oka M, Matsumoto N, Ouchida R, Hong J, Hashizume M. Warning nWarning navigation system using real-time safe region monitoring for otologic surgery. Int J Comput Assist Radiol Surg 2013;8:395-405

11. Hong J, Hashizume M. An effective point-based registration tool for surgical navigation. Surg Endosc 2010; 24:944-948

12. Lee S, Kim JY, Hong J, Baek SH, Kim SY. CT-based navigation system using a patient-specific instrument for femoral component positioning: an experimental in vitro study with a sawbone model. Yonsei Med J 2018; 59:769-780

13. Oka M, Cho B, Matsumoto N, Hong J, Jinnouchi M, Ouchida R, et al. A preregistered STAMP method for image-guided temporal bone surgery. Int J Comput Assist Radiol Surg 2014;9:119-126

14. Jeon S, Park J, Chien J, Hong J. A hybrid method to improve target registration accuracy in surgical navigation. Minim Invasive Ther Allied Technol 2015;24:356-363

15. Hong J, Matsumoto N, Ouchida R, Komune S, Hashizume M. Medical navigation system for otologic surgery based on hybrid registration and virtual intraoperative computed tomography. IEEE Trans Biomed Eng 2009; 
56:426-432

16. Lee S, Lee H, Choi H, Jeo S, Ha H, Hong J, Comparative study of hand-eye calibration methods for augmented reality using an endoscope. J Electron Imaging 2018;27:043017

17. Lee S, Lee H, Choi H, Jeon S, Hong J, Effective calibration of an endoscope to an optical tracking system for medical augmented reality. Cogent Eng 2017;4:1359955

18. Cho B, Oka M, Matsumoto N, Ouchida R, Hong J, Hashizume M. Warning navigation system using real-time safe region monitoring for otologic surgery. Int J Comput Assist Radiol Surg 2013;8:395-405

19. Cho HS, Park YK, Gupta S, Yoon C, Han I, Kim HS, et al. Augmented reality in bone tumour resection: an experimental study. Bone Joint Res 2017;6:137-143

20. Ha HG, Jeon S, Lee S, Choi H, Hong J. Perspective pinhole model with planar source for augmented reality surgical navigation based on C-arm imaging. Int J Comput Assist Radiol Surg 2018;13:1671-1682

\section{의료용 증강현실 및 가상현실}

\section{홍 재 성*}

증강현실 또는 가상현실 기술은 의료를 포함해 교육이나, 오락, 산업 영역에서 최근 적극적 으로 연구되고 있다. 특히 복강경이나 여러 내시경, 수술 현미경, 카테터 등을 사용하는 수술 이 늘어남에 따라 그 중요성이 증가하고 있다. 증강현실은 현실 세계와 가상의 물체를 연결 하는 기술로 표현될 수 있는데, 가상의 물체들은 주로 컴퓨터에 의해 인공적으로 생성된 그 래픽 객체들이다. 따라서 현실 세계와 가상의 물체간의 정확한 정합이 중요한 기술적 목표라 고 할 수 있다. 실물을 보여주는 영상 위에 가상의 정보들을 부가하여 표시할 수 있는데, 이 기술을 이용하여 시술자는 장기 내부에 있는 종양이나 혈관, 신경 등 육안으로 볼 수 없는 조 직들의 위치나 형상을 확인할 수 있으며, 시술의 정확도와 안전성을 향상시킬 수 있다. 본 기 고에서는 증강현실에 초점을 두고 관련 기술들과 과제들을 서술하고, 응용 예를 소개한다.

대구경북과학기술원 로봇공학과 